\title{
Effect of Nutrient Management on Population Growth of Brown Planthopper, Nilaparvata lugens (Stål)
}

\author{
M M Rashid ${ }^{1}$, M Jahan², K S Islam², M N Bari³ and S S Haque ${ }^{4}$
}

\begin{abstract}
Brown planthopper (BPH), Nilaparvata lugens (Stål) is a major insect pest of rice in Bangladesh. Nutrient management in rice received little attention on $\mathrm{BPH}$ population. The present study evaluated the consequences of nitrogen $(\mathrm{N})$, phosphorus $(\mathrm{P})$ and potassium $(\mathrm{K})$ application on population build up and weight of $\mathrm{BPH}$ in the laboratory and net-house at Entomology Division, Bangladesh Rice Research Institute. Three levels of soil nitrogen (0, 100, $\left.200 \mathrm{~kg} \mathrm{~N} \mathrm{ha}^{-1}\right)$, phosphorus (0, 20, $\left.40 \mathrm{~kg} \mathrm{P}_{2} \mathrm{O}_{5} \mathrm{ha}^{-1}\right)$ and potassium $\left(0,60,120 \mathrm{~kg} \mathrm{~K}_{2} \mathrm{O} \mathrm{ha}^{-1}\right)$ were compared for individual and combined effects. Interactions of N, P and $\mathrm{K}$ demonstrated no significant effect on population growth and weight of BPH. However, interaction of $\mathrm{N}$ and $\mathrm{P}$ showed significant effect on population growth of BPH. Fertilization with nitrogen increased population and dry weight of BPH. Phosphorus fertilization markedly increased the population growth while high potassium application decreased population build up and dry weight of $\mathrm{BPH}$.
\end{abstract}

Key words: BPH, nitrogen, phosphorus, potassium, growth, weight.

\section{INTRODUCTION}

Rice is the most important staple food worldwide and concerns the worlds' largest populations of farmers and consumers (Zeigler and Barclay, 2008). It is the predominant food crop of Bangladesh and occupies about $77 \%$ of the cropped areas and provides about $75 \%$ of the calorie and $55 \%$ of the protein in average daily diet of a Bangladeshi (Bhuiyan et al., 2004). Recently brown planthopper (BPH), Nilaparvata lugens (Stål) (Homoptera: Delphacidae) has one of the most important insect pests of rice all over the world including Bangladesh (Ali et al., 2014; Bottrell and Schoenly, 2012). Host plant quality plays a major role in the population biology of BPH. The plant nutrient status is an indicator of host plant quality, which plays an important role in the population dynamics of many herbivores (Cook and Denno, 1994). Nitrogen is one of the most important factors in development of phytophagous insects ( $\mathrm{Lu}$ et al., 2007). Populations of many insect species have been reported to increase significantly with higher nitrogen level (Dale, 1988; Chau et al., 2003; Throop and Lerdau, 2004; Hogendorp, 2006; Lu and Heong, 2009; El-Zahi et at., 2012). There is a scope of greater population buildup of BPH (Preap et al., 2001; Lu and Heong, 2009) resulting in a higher tendency for outbreaks in high nitrogen applied rice fields (Uhm et al., 1985; Hosamani et al., 1986; Li et al., 1996).

Phosphorus $(\mathrm{P})$ has not been considered as important or limiting as nitrogen for phytophagous insects including BPH. However, few studies that have been investigated the effects of phosphorus on different insects, which showed that it could be an important determinant of growth rate (Sterner and Hessen, 1994; Elser et al., 2000, 2001, 2003; Urabe and Sterner, 2001; Eskelinen, 2002; Fagan et al., 2002; Schade et al., 2003; Perkins et al., 2004)

\footnotetext{
${ }^{1}$ Senior Scientific Officer, Plant Physiology Division, Bangladesh Rice Research Institute, Gazipur 1701.

2 Professor, Department of Entomology, Bangladesh Agricultural University, Mymensingh 5022.

${ }^{3}$ Senior Scientific Officer, Entomology Division, Bangladesh Rice Research Institute, Gazipur 1701.

4 Principal Scientific Officer, Entomology Division, Bangladesh Rice Research Institute, Gazipur 1701.

Corresponding author's email: mrashidbrri@gmail.com
} 
and population density (Slamn, 2002; Schade et al., 2003) of invertebrates. Phosphorus may be a much more important component for the population growth of phytophagous insects as it required for RNA synthesis. It can impose severe consequences for the growth rate of consumers i.e. invertebrates when it is limiting (Sterner and Elser, 2002).

Populations of many insect species have been reported to be affected adversely by K (Salim, 2002b; Sarwar et al., 2011; El-Zahi, 2012; Sarwar, 2012). Potassium (K) is an essential element for the growth of rice plant and takes part in various physiological processes (Tisdale et al., 1985; Wyn Jones, 1999). Amtmann (2008) reported that potassium nutrition has a profound effect on the profile and distribution of primary metabolites in plant tissues, which in turn could affect the attractiveness of the plant for insects as well as their subsequent growth and development on the plant. The primary metabolites such as soluble sugars particularly reducing sugars, organic acids and amino acids tend to increase in $\mathrm{K}$ deficient plants. It has been reported that the negative influence of high levels of $\mathrm{K}$ on insect populations is due to a reduced carbohydrate accumulation and elimination of amino acids (Baskaran et al., 1985), higher silica content and increase in the sclerenchymous layer (Dale, 1988).

The studies on the effects of nitrogen, phosphorus and potassium on the population development of $\mathrm{BPH}$ are limited and have not been empirically tested in Bangladesh. Therefore, the present research work has been planned and designed to investigate the influence of plant nutrient levels on population build up and weight of $\mathrm{BPH}$.

\section{MATERIALS AND METHODS}

\section{Preparation of soil and host plant establishment}

Soil was fertilized with 3 levels of nitrogen subsidy $\left(0,100,200 \mathrm{~kg} \mathrm{~N}^{-1}\right), 3$ levels of phosphorous $\left(0,20,40 \mathrm{~kg} \mathrm{P}_{2} \mathrm{O}_{5}\right.$ ha- $\left.^{-1}\right)$ and 3 levels of potassium $\left(0,60,120 \mathrm{~kg} \mathrm{~K}_{2} \mathrm{O}\right.$ ha-1) and combination of all the levels. The potted plants of different fertilizer doses were prepared separately for the experiments. Half of the $\mathrm{N}$ fertilizer (in the form of Urea) and the whole of $\mathrm{P}$ (in the form of Triple super phosphate, TSP) and K (in the form of Muriate of Potash, MP) were mixed in the soil. The remaining half of $\mathrm{N}$ was applied when the plants were 30-dayold. The macronutrient treatments are here after referred to as $\mathrm{N}_{0}, \mathrm{~N}_{100}$ and $\mathrm{N}_{200}$ for nitrogen, $\mathrm{P}_{0}, \mathrm{P}_{20}$ and $\mathrm{P}_{40}$ for phosphorus and $\mathrm{K}_{0}, \mathrm{~K}_{60}$ and $\mathrm{K}_{120}$ for potassium. Fifteen-day-old rice seedlings of variety BR3 were transplanted ( 3 hills/pot and 2 seedlings/ hill) in each earthen pot. Plants with different fertilizer doses were labeled and placed under natural condition. As, one hectare cultivated field contains $2 \times 10^{6} \mathrm{~kg}$ soil in its root zone. So, the exact amount of fertilizers inputs to be applied to each pot was calculated based on the amount of soil in each pot (Asher et al., 2002).

\section{Culture of brown planthopper}

Brown planthopper $(\mathrm{BPH})$ population required for the experiments were obtained from a mass culture maintained in the green house throughout the period of study with the susceptible variety BR3. Forty five to sixty-day-old potted rice plants were used for this purpose. The plants were cleaned and the outer leaf sheaths of the potted plants were removed to destroy the eggs of other insects if any. Those potted plants were kept in iron framed rearing cage covered by the fine mesh wire net on a tray filled with water to onethird of its height, so that the soil could not dry. Gravid BPH adults were released in a cage with the rice plants for oviposition and those removed 24 hours later using by an aspirator (a mouth sucking device). The potted plants with BPH eggs were then shifted every day to a 
series of rearing cages for hatching of the eggs to ensure supply of same aged BPH. After hatching, the host plants in the cage were changed at 3-4 days interval to provide sufficient food for the development of the nymphs to adulthood. To obtain steady supply host plant materials for each $\mathrm{BPH}$ culture and experiment, seedlings were transplanted at 15-day intervals.

\section{Nutrients experiments of brown planthopper}

Yellow leaf sheaths were removed from forty-five day-old potted rice plants of different fertilizer doses and were infested with a pair of freshly molted adult for each treatment. The plants were covered with transparent mylar cages for population build up. Males and females were checked after 24 hours of infestation, and one pair of insects were ensured in each cage by eliminating the superfluous or by supplying additional. At 25 days after release of the adult all insects were collected in flasks containing ethyl acetone and counted. Fresh weight of twenty female adult BPH was measured to get mean fresh body weight and then all of the BPH were dried in the oven at $60{ }^{\circ} \mathrm{C}$ for 48 hours until constant weight and recorded total dry weight of $\mathrm{BPH}$. Factorial $(3 \times 3 \times 3)$ pot experiments were laid out in Completely Randomized Design (CRD) with 27 treatment combinations and four replications.

\section{Statistical analysis}

The data of number and dry weight of BPH was transformed into Square-Root transformation and those were analyzed using MSTAT-C programme. The mean differences among the treatments were compared by multiple comparison tests using Duncan's Multiple Range Test (DMRT) at 5\% level.

\section{RESULTS}

Interactions of $\mathrm{N}$ and $\mathrm{K}, \mathrm{P}$ and $\mathrm{K}$, and all three nutrients ( $\mathrm{N}, \mathrm{P}$ and $\mathrm{K}$ ) were insignificant for the brown planthopper population build up. The $\mathrm{N}$ and $\mathrm{P}$ interaction was significant on brown planthopper population development (Table 1). Number of BPH individuals in $\mathrm{F}_{1}$ generation from one pair of adult $\mathrm{BPH}$ varied greatly by the application of nitrogen to the host plants. It was increased significantly with the increase of nitrogen application (Fig. 1). The highest number of brown planthopper (207.6) was recorded in the plants fertilized with the treatment $\mathrm{N}_{200}$ (Table 2). There were also marked increases of population build up of brown planthopper when reared on the higher phosphorus regimes (Fig. 1). Number of brown planthopper produced from one pair of adult did not differ significantly in the treatments of $\mathrm{P}_{20}$ and $\mathrm{P}_{40}$ (Table 3). $\mathrm{BPH}$ population was reduced significantly at the highest rate of potassium $\left(\mathrm{K}_{120}\right)$ fertilized plants (Fig. 1). However, population build up was comparable between $\mathrm{K}_{0}$ and $\mathrm{K}_{60}$ fertilized plants (Table 4). Dry weight of BPH from one pair of adults varied greatly by the application of nitrogen to their host plants and increased significantly with the increase of nitrogen application (Fig. 2). The highest dry weight (62.92) was recorded in the plants by the application of $200 \mathrm{~kg} \mathrm{~N}^{-1}$ (Table 2). There were also marked increases of dry weight of female brown planthopper when reared on the higher phosphorus regimes (Fig. 2). However, dry weight gained from one pair of adults did not differ significantly in the application of $\mathrm{P}_{20}$ and $\mathrm{P}_{40}$ (Table 3). The $\mathrm{N}$ and $\mathrm{P}$ interaction was significant on dry weight of BPH (Table 1). Dry weight of BPH was reduced significantly at the highest rate of potassium $\left(\mathrm{K}_{120}\right)$ fertilized plants (Fig. 2). However, there was no significant difference in $\mathrm{K}_{0}$ and $\mathrm{K}_{60}$ treatments (Table 4). Interaction of $\mathrm{N}$ and $\mathrm{K}, \mathrm{P}$ and $\mathrm{K}$, and 
all three nutrients $(\mathrm{N}, \mathrm{P}$ and $\mathrm{K})$ were insignificant for the dry weight gained of brown planthopper (Table 1).

Table 1. Analysis of variance for population growth of BPH and plant damage as affected by N, P and K at BRRI, Gazipur

\begin{tabular}{|c|c|c|c|c|}
\hline \multirow{2}{*}{$\begin{array}{l}\text { Source of } \\
\text { variation }\end{array}$} & \multirow[b]{2}{*}{$\mathrm{df}$} & \multicolumn{3}{|c|}{ Mean Square } \\
\hline & & $\begin{array}{l}\text { BPH population } \\
\text { build up }\end{array}$ & $\begin{array}{l}\text { Total dry weight of } \\
\text { BPH population }\end{array}$ & $\begin{array}{l}\text { Fresh weight of } \\
\text { female adult BPH }\end{array}$ \\
\hline $\mathrm{N}$ & 2 & 269.393 ** & 138.222 ** & $3.52954 * *$ \\
\hline $\mathrm{P}$ & 2 & 4.956 ** & 1.078 ** & $0.339185 \mathrm{E}-01$ * \\
\hline NP & 4 & 0.984 ** & 0.270 * & $0.175926 \mathrm{E}-01$ * \\
\hline K & 2 & $2.070 * *$ & 0.711 ** & $0.148148 \mathrm{E}-02 \mathrm{~ns}$ \\
\hline NK & 4 & $0.296 \mathrm{~ns}$ & $0.055 \mathrm{~ns}$ & $0.370370 \mathrm{E}-03 \mathrm{~ns}$ \\
\hline PK & 4 & $0.103 \mathrm{~ns}$ & $0.022 \mathrm{~ns}$ & $0.564815 \mathrm{E}-02 \mathrm{~ns}$ \\
\hline NPK & 8 & $0.193 \mathrm{~ns}$ & $0.078 \mathrm{~ns}$ & $0.162037 \mathrm{E}-02 \mathrm{~ns}$ \\
\hline Error & 81 & 0.265 & 0.093 & $0.703704 \mathrm{E}-02$ \\
\hline Total & 107 & & & \\
\hline CV (\%) & & 4.20 & 4.71 & 4.88 \\
\hline
\end{tabular}

$n s=$ Non significant

* = Significant at $5 \%$ level of probability

** = Significant at $1 \%$ level of probability Replication- 4
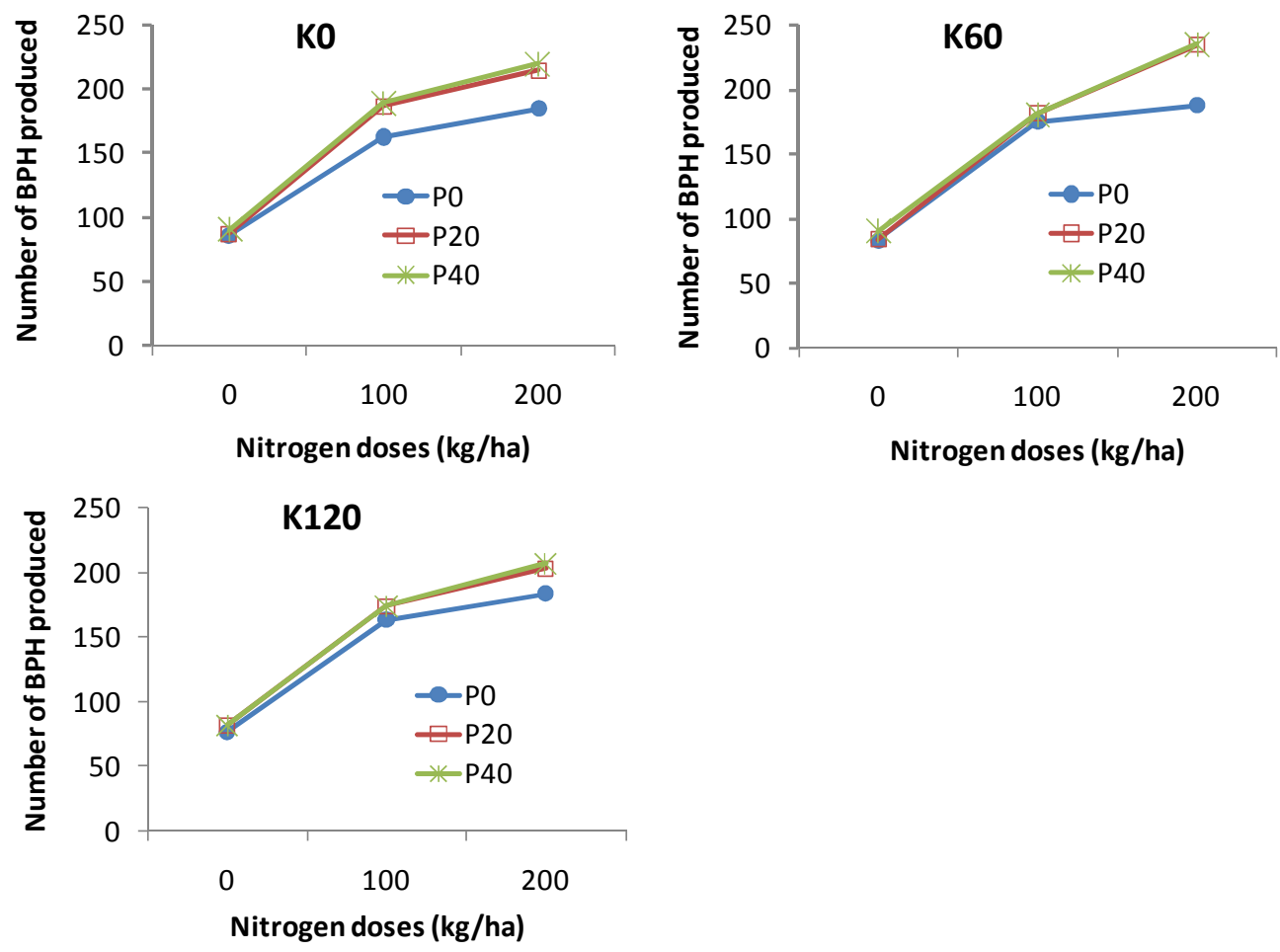

Fig 1. Interaction effect of nitrogen, phosphorus and potassium (N, P and $K)$ on BPH population development at BRRI, Gazipur 
Table 2. Mean effect of nitrogen on population buildup and weight of BPH at BRRI, Gazipur

\begin{tabular}{|c|c|c|c|}
\hline $\begin{array}{l}\text { N level } \\
\left(K g \text { ha-1 }^{-1}\right)\end{array}$ & $\begin{array}{l}\text { BPH population } \\
\text { build up } \\
\text { (Mean } \pm \text { SE ) }\end{array}$ & $\begin{array}{c}\text { Total dry weight of BPH } \\
(\mathrm{mg}) \\
(\text { Mean } \pm \text { SE })\end{array}$ & $\begin{array}{c}\text { Fresh weight of BPH } \\
(\mathrm{mg} / \text { female }) \\
(\text { Mean } \pm \mathrm{SE})\end{array}$ \\
\hline $\mathrm{N}_{0}$ & $\begin{array}{c}84.75 \pm 1.41 \mathrm{c} \\
(9.18)\end{array}$ & $\begin{array}{c}18.16 \pm 0.32 \mathrm{c} \\
(4.24)\end{array}$ & $1.38 \pm 0.03 c$ \\
\hline $\mathrm{N}_{100}$ & $\begin{array}{c}176.3 \pm 3.04 \mathrm{~b} \\
(13.25)\end{array}$ & $\begin{array}{c}53.09 \pm 0.82 \mathrm{~b} \\
(7.27)\end{array}$ & $1.78 \pm 0.03 b$ \\
\hline $\mathrm{N}_{200}$ & $\begin{array}{c}207.6 \pm 6.63 \mathrm{a} \\
(14.39)\end{array}$ & $\begin{array}{c}62.92 \pm 1.80 \mathrm{a} \\
(7.92)\end{array}$ & $1.99 \pm 0.03 \mathrm{a}$ \\
\hline F value & 1014.79 & 1484.01 & 501.56 \\
\hline F Prob & ** & $* *$ & ** \\
\hline
\end{tabular}
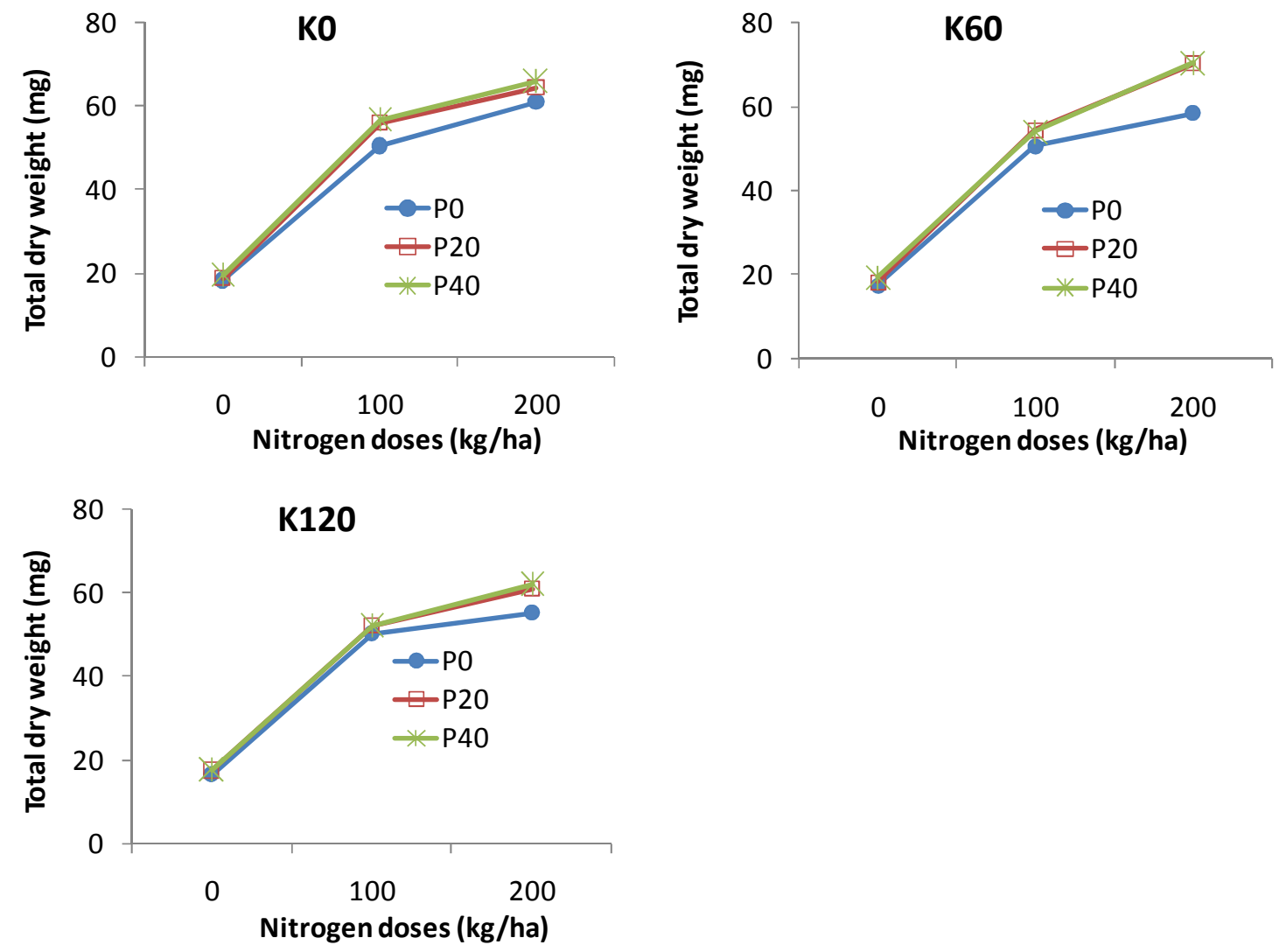

Fig 2. Interaction effect of nitrogen, phosphorus and potassium (N, P and $K)$ on total dry weight of BPH at BRRI, Gazipur 
Table 3. Mean effect of phosphorus on population buildup and weight of BPH at BRRI, Gazipur.

\begin{tabular}{l|c|c|c}
\hline $\begin{array}{l}\text { P level } \\
\left(\text { Kg ha }^{-1}\right)\end{array}$ & $\begin{array}{c}\text { BPH population } \\
\text { build up } \\
\text { (Mean } \pm \text { SE })\end{array}$ & $\begin{array}{c}\text { Total dry weight of BPH } \\
(\mathrm{mg}) \\
(\text { Mean } \pm \text { SE })\end{array}$ & $\begin{array}{c}\text { Fresh weight of BPH } \\
(\mathrm{mg} / \mathrm{female}) \\
(\text { Mean } \pm \mathrm{SE})\end{array}$ \\
\hline $\mathrm{P}_{0}$ & $\begin{array}{c}144.94 \pm 15.96 \mathrm{~b} \\
(11.85)\end{array}$ & $\begin{array}{c}41.90 \pm 6.22 \mathrm{~b} \\
(6.28)\end{array}$ & $1.60 \pm 0.09 \mathrm{~b}$ \\
$\mathrm{P}_{20}$ & $160.91 \pm 19.98 \mathrm{a}$ & $45.88 \pm 7.14 \mathrm{a}$ & $1.75 \pm 0.09 \mathrm{a}$ \\
$\mathrm{P}_{40}$ & $(12.44)$ & $(6.55)$ & $1.79 \pm 0.09 \mathrm{a}$ \\
& $162.93 \pm 19.92 \mathrm{a}$ & $46.39 \pm 7.16 \mathrm{a}$ & 4.82 \\
\hline F Value & $(12.53)$ & $(6.60)$ & $*$ \\
\hline F Prob & 18.67 & 11.57 & \\
\hline
\end{tabular}

- Means followed by the same letters are not significantly different (Duncan's multiple range test), average of four replications.

- Data within parenthesis are transformed values.

- Data were transformed using Square-Root transformation.
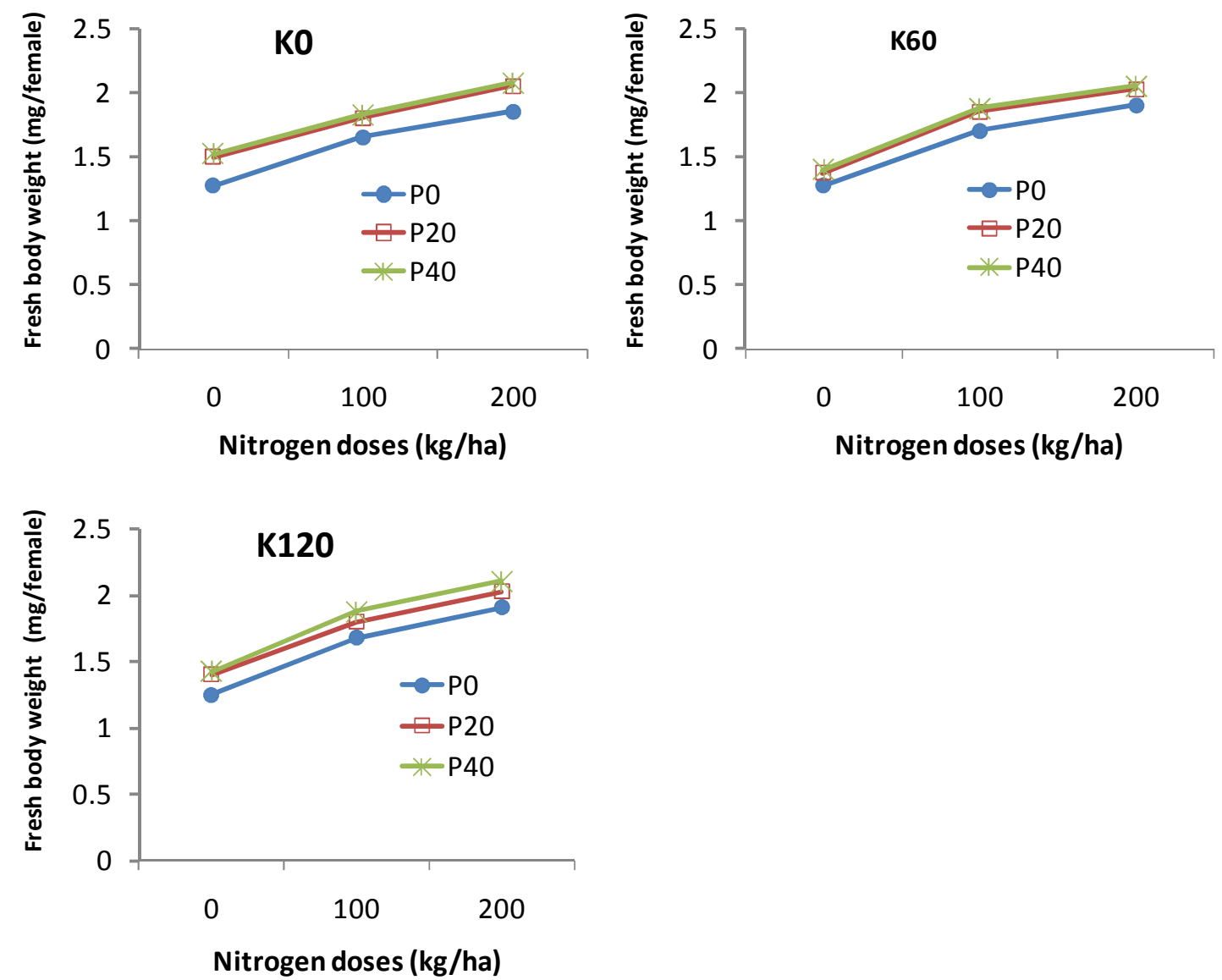

Fig 3. Interaction effect of nitrogen, phosphorus and potassium (N, P and $K)$ on fresh body weight of female BPH at BRRI, Gazipur 
Table 4. Mean effect of potassium on population buildup and dry weight of BPH at BRRI, Gazipur

\begin{tabular}{|c|c|c|c|}
\hline $\begin{array}{l}\text { K level } \\
\left(K^{\prime} \text { ha-1) }\right.\end{array}$ & $\begin{array}{l}\text { BPH population } \\
\text { build up } \\
\text { (Mean } \pm \text { SE })\end{array}$ & $\begin{array}{c}\text { Total dry weight of BPH } \\
(\mathrm{mg}) \\
(\text { Mean } \pm \text { SE })\end{array}$ & $\begin{array}{c}\text { Fresh weight of BPH } \\
\text { (mg/female) } \\
\text { (Mean } \pm \text { SE) }\end{array}$ \\
\hline $\mathrm{K}_{0}$ & $\begin{array}{c}157.8 \pm 18.31 \mathrm{a} \\
(12.37)\end{array}$ & $\begin{array}{c}45.65 \pm 6.87 \mathrm{a} \\
(6.56)\end{array}$ & $1.73 \pm 0.09$ \\
\hline $\mathrm{K}_{60}$ & $\begin{array}{c}161.2 \pm 20.27 \mathrm{a} \\
(12.45)\end{array}$ & $\begin{array}{c}45.94 \pm 7.22 \mathrm{a} \\
(6.56)\end{array}$ & $1.71 \pm 0.10$ \\
\hline $\mathrm{K}_{120}$ & $\begin{array}{c}149.6 \pm 17.91 \mathrm{~b} \\
(12.00)\end{array}$ & $\begin{array}{c}42.58 \pm 6.50 \mathrm{~b} \\
(6.31)\end{array}$ & $1.71 \pm 0.10$ \\
\hline F Value & 7.79 & 7.62 & 0.21 \\
\hline F Prob & $* *$ & ** & ns \\
\hline
\end{tabular}

The nitrogen fertilization to the rice plants strongly influenced fresh body weights of female brown planthopper. The fresh weight of female adult was greatly increased with the increase of nitrogen application to rice plants and the increase was linear (Fig. 3). Females were significantly heavier when reared on plants in $\mathrm{N}_{100}$ and $\mathrm{N}_{200}$ regimes than in the $\mathrm{N}_{0}$ regime (Table 2). Phosphorus fertilization to rice plants at the rates of $P_{20}$ and $P_{40}$ also increased fresh weight of brown planthopper when compared to no phosphorus fertilizer $\left(\mathrm{P}_{0}\right)$ was added (Fig. 3). There was no significant increase in fresh weight of brown planthopper from $\mathrm{P}_{20}$ to $\mathrm{P}_{40}$ treatment levels (Table 3). The $\mathrm{N}$ and $\mathrm{P}$ interaction was significant for body weight of freshly developed adult BPH (Table 1) and it was maximum when both nitrogen and phosphorus were applied at higher doses $\left(\mathrm{N}_{200}\right.$ and $\left.\mathrm{P}_{40}\right)$ (Fig. 3). However, brown planthopper reared on rice plants with increased potassium subsidies did not show any change in fresh weights of female adults (Table 4). Interaction of $\mathrm{N}$ and $\mathrm{K}, \mathrm{P}$ and $\mathrm{K}$, and all three nutrients (N, P and $\mathrm{K})$ were insignificant for fresh weight of $\mathrm{BPH}$ adult (Table 1).

\section{DISCUSSION}

The present study showed that the number of BPH and their weight was increased when fed on high nitrogen regimes host plants, while on low nitrogen regimes they were reduced. These results were also in agreement with other studies (Heinrichs and Medrano, 1985; Lu et al., 2004). They reported that the number of BPH and dry mass from one pair of parents were significantly higher in high nitrogen plants. Body weight and number of $\mathrm{BPH}$ increased with the increasing level of nitrogen fertilizer on both susceptible and resistant rice varieties (Heinrichs and Medrano, 1985; Prasad et al., 2003, 2005). Application of nitrogen fertilizer produced more tillers and biomass of rice (Salim, 2002a; Chau et al., 2003) which resulted in a thick and humid canopy that might provide a favourable microenvironment for population development of BPH (Lu et al., 2007). Salim (2002a) reported that increase in nitrogen induced succulence in rice plants which makes them more prone to insect pests. Moreover, the high BPH population in nitrogen applied plants might be due to an increase in soluble protein and free sugar content in rice sap. Numbers of studies showed that soluble amino acid in plants increase nutritional value for insects. (Hu et al., 1986; Kajimura et al., 1995). 
The number of $\mathrm{BPH}$ produced and dry weight gained from one pair of BPH markedly increased by phosphorus fertilization to rice plants (Table 3). Some authors reported that, phosphorus supplementation did result in enhanced population density (Slamn, 2002; Schade et al., 2003; Huberty and Denno, 2006) and increased body size (Janssen, 1994; Busch and Phelan, 1999; Huberty and Denno, 2006) of different insects.

The number of BPH and dry weight were markedly reduced when potassium fertilizer was applied to rice plants at the highest dose (Table 4). This might be due to decrease in soluble protein and free sugar content in those plants. Salim (2002b) reported that deficiency of K in rice plants increased population build up of white backed planthopper, Sogatella furcifera and application of high dose of $\mathrm{K}$ to rice plants decreased population build up of the insect. Higher rate of potash fertilizer was associated with lower BPH population (Samiayyan and Janarathanan, 1988, 1990). Plants fertilized with potassium either alone or in combinations with others were infested significantly with the lowest population densities of Impoasca spp. and Aphis gossypii and were infested with moderate numbers of Bemisia tabaci (El-Zahi et at., 2012). The negative effects of $K$ fertilizer were also shown by Parihar and Upadhyay (2001) on leafhoppers and mites.

\section{CONCLUSION}

Application of nitrogen increased population growth of $\mathrm{BPH}$. Phosphorus fertilization showed a little or no effect on $\mathrm{BPH}$ growth but fertilization with the highest rate of potassium showed reduction effect. The rice growing areas where BPH populations grow with better ecological fitness due to result of application of high nitrogen fertilizer could be vulnerable to BPH outbreaks.

\section{REFERENCES}

Ali, M P, D Huang, G Nachman, N Ahmed, M A Begum and M F Rabbi. 2014. Will Climate Change Affect Outbreak Patterns of Planthoppers in Bangladesh? PLoS ONE 9(3): e91678. doi:10.1371/journal.pone.0091678.

Amtmann, A, S Troufflard and P Armengaud. 2008. The effect of potassium nutrition on pest and disease resistance in plants. Physiol. Plant., 133: 682-691.

Asher, C, N Grundon and NN Menzies. 2002. How to Unravel and Solve Soil Fertility Problems. ACIAR Monograph. No. 83, p. 139.

Baskaran, P, P Narayanasamy and A Pari. 1985. The role of potassium in incidence of insect pests among crop plants, with particular reference to rice. In: Role of Potassium in Crop Resistance to Insect Pests. Research Series no. 3, Potash Research Institute of India, Guragaon, Haryana, India. pp. 63-68.

Bhuiyan, N I, D N R Paul and M A Jabber. 2004. Feeding the extra millions by 2025: Challenges for rice research and extension in Bangladesh. In: M M Haque, A R Gomosta and M R Mandal (eds.) Proceedings of the Workshop on Modern Rice Cultivation in Bangladesh. Bangladesh Rice Research Institute, Gazipur, Bangladesh. pp. 1-24.

Bottrell, D G and K G Schoenly. 2012. Resurrecting the ghost of green revolutions past: The brown planthopper as a recurring threat to high-yielding rice production in tropical Asia. J. Asia-Pacific Entomol., 15:122-140.

Busch, J W and L Phelan. 1999. Mixture models of soybean growth and herbivore performance in response to nitrogen-sulphur-phosphorus nutrient interactions. Ecol. Entomol., 24:132-145. 
Chau, L M, H D Cat, P T Ben, L T Phuong, J Cheng and K L Heong. 2003. Impacts of nutrition management on insect pests and diseases of rice. Omonrice, 11: 93-102.

Cook, A G and R F Denno. 1994. Planthopper/ plant interactions: Feeding behavior, plant nutrition, plant defense and host plant specialization. In: R F Denno and T J Perfect (eds.) Planthoppers: Their Ecology and Management. Chapman and Hall, London, UK. pp. 114-139.

Dale, D. 1988. Plant mediated effects of soil mineral stress on insects. In: E A Heinrich (ed.) Plant Stress Insect Interactions. John Wiley and Sons, New York, USA. pp. 35-110.

Elser, J J, W F Fagan, R F Denno, D R Dobberfuhl, A Folarin, A Huberty, S Interlandi, S S Kilham, E McCauley, K L Schulz, E H Siemann and R W Sterner. 2000. Nutritional constraints in terrestrial and freshwater food webs. Nature, 408: 578-580.

Elser, J J, K Hayakawa and J Urabe. 2001. Nutrient limitation reduces food quality for zooplankton: Daphnia response to seston phosphorus enrichment. Ecology, 82: 898-903.

Elser, J J, K Acharya, M Kyle, J B Cotner, W Makino, T A Markow, T Watts, S Hobbie, W Fagan, J Schade, J Hood and R W Sterner. 2003. Growth rate- stoichiometry couplings in diverse biota. Ecol. Lett., 6: 936-943.

El-Zahi, E S, S A Arif, B A Jehan, El-Naggar, E H Madeha and El-Dewy. 2012. Inorganic fertilization of cotton field-plants in relation to sucking insects and yield production components of cotton plants. J. Am. Sci., 8: 509-517.

Eskelinen, O. 2002. Diet of the wood lemming Myopus schisticolor. Ann. Zool. Fenn., 39: 4957.

Fagan, W F, E H Siemann, R F Denno, C Mitter, A Huberty, H A Woods and J J Elser. 2002. Nitrogen in insects: implications for trophic complexity and species diversification. Am. Nat., 160: 784-802.

Heinrichs, E A and F G Medrano. 1985. Influence of nitrogen fertilizer on the population development of brown planthopper. Intl. Rice Res. Newsl., 10: 20-21.

Hogendorp, B K, R A Cloyd and J M Swiader. 2006. Effect of nitrogen fertility on reproduction and development of citrus mealybug, Planococcus citri Risso (Homoptera: Pseudococcidae), feeding on two colors of coleus, Solenostemon scutellarioides L. Codd. Environ. Entomol., 35: 201-211.

Hosamani, M M, B Jayakumar and K M S Sharma. 1986. Sources and levels of nitrogenous fertilizers in relation to incidence of brown planthopper in Bhadra project. Current Res., 15: 132-134.

Hu, J Z, Q H Lu, J S Yang and L P Yang. 1986. Effects of fertilizers and irrigation on the population of main insect pests and the yield of rice. Acta Entomol. Sin., 29: 49-54.

Huberty, F A and R F Denno. 2006. Consequences of nitrogen and phosphorus limitation for the performance of two planthoppers with divergent life-history strategies. Oecologia, 149: 444-455.

Janssen, J A M. 1994. Impact of the mineral composition and water content of excised maize leaf sections on fitness of the African armyworm, Spodoptera exempta (Lepidoptera: Noctuidae). Bull. Entomol. Res., 84: 233-245.

Kajimura T, K Fujisaki and Nakasuji. 1995. Effect of organic rice farming on leaffolder and planthoppers: 2. Amino acid content in the rice phloem sap and survival rate of planthoppers. Appl. Entomol. Zool., 30: 17-22.

Li, R D, J H Ding, G W Hu and D M Shu. 1996. The Brown Planthopper and its Population Management. Fudan University Press, Shanghai, Chaina. p. 334. 
Lu, Z X and K L Heong. 2009. Effects of nitrogen-enriched rice plants on ecological fitness of planthoppers In: KL Heong and B Hardy (eds.) Planthoppers: New Threats to the Sustainability of Intensive Rice Production Systems in Asia. International Rice Research Institute, Los Baños, Philippines. pp. 247-256.

Lu, Z X, K L Heong, X P Yu and C Hu. 2004. Effects of plant nitrogen on ecological fitness of the brown planthopper, Nilaparvata lugens in rice. J. Asia-Pacific Entomol., 7: 97-104.

$\mathrm{Lu}, \mathrm{Z}$ X, X P Yu, K L Heong and C Hu. 2007. Effect of nitrogen fertilizer on herbivores and its stimulation to major insect pests in rice. Rice Sci., 14: 56-66.

Parihar, S B S and N C Upadhyay. 2001. Effect of fertilizers (NPK) on incidence of leafhoppers and mite in potato crop. Insect Environ., 7: 10-11.

Perkins, M C, H A Woods, J F Harrison and J J Elser. 2004. Dietary phosphorus affects the growth of larval Manduca sexta. Arch. Insect Biochem. Physiol., 55: 153-168.

Prasad, B R, I C Pasalu, N B T Raju and N R G Verma. 2003. Influence of nitrogen and rice varieties on population buildup of brown planthopper, Nilaparvata lugens (Stal.). J. Entomol. Res., 27: 167-170.

Prasad, B R, I C Pasalu, N B T Raju and T Lingaiah. 2005. Effect of nitrogen levels and rice varieties on brown planthopper adult weight and amount of honeydew excretion. Ann. Plant Prot. Sci., 13: 1.

Preap, V, M P Zalucki, H J Nesbitt and G C Jahn. 2001. Effect of fertilizer, pesticide treatment and plant variety on realized fecundity and survival rates of Nilaparvata lugens (Stål); generating outbreak in Cambodia. J. Asia-Pacific Entomol., 4: 75-84.

Salim, M. 2002a. Nitrogen induced changes in rice plants: Effect on host-insect interactions. Pakistan J. Agric. Res., 17: 210-219.

Salim, M. 2002b. Effects of potassium nutrition on growth, biomass and chemical composition of rice plants and on host-insect interaction. Pakistan J. Agric. Res., 17: $14-21$.

Samiayyan, K and R Janarathanan. 1988. An appraisal of potash fertilization in controlling the incidence of leaf and planthoppers in some rice varieties. J. Potassium Res., 4: 6166.

Samiayyan, $\mathrm{K}$ and $\mathrm{R}$ Janarathanan. 1990. Influence of $\mathrm{K}$ in combination with $\mathrm{N}$ on the incidence of BPH in rice. J. Potassium Res., 6: 36-41.

Sarwar, M. 2012. Effects of potassium fertilization on population build up of rice stem borers (lepidopteron pests) and rice (Oryza sativa L.) yield. J. Cereals Oilseeds, 3: 6-9.

Sarwar, M, N Ahmad and M Tofique. 2011. Impact of soil potassium on population buildup of aphid (Homoptera: Aphididae) and crop yield in canola (Brassica napus L.) field. Pakistan J. Zool., 43: 15-19.

Schade, J D, M Kyle, S E Hobbie, W F Fagan and J J Elser. 2003. Stoichiometric tracking of soil nutrients by a desert insect herbivore. Ecol. Lett., 6: 96-101.

Slamn, F A A. 2002. Effect of some agricultural practices on the population density of cowpea aphid, Aphis craccivora Koch infesting broad bean plants in upper Egypt. Assiut J. Agric. Sci., 33: 13-20.

Sterner, R W and J J Elser. 2002. Ecological Stoichiometry: The biology of Elements from Molecules to the Biosphere. Princeton University Press, Princeton, New Jersey, USA. p. 584.

Sterner, R W and D O Hessen. 1994. Algal nutrient limitation and the nutrition of aquatic herbivores. Annu. Rev. Ecol. Syst., 25: 1-29. 
Throop, H L and M T Lerdau. 2004. Effects of nitrogen deposition on insect herbivory: Implications for community and ecosystem processes. Ecosystems, 7: 109-133.

Tisdale, S L, W L Nelson and J D Beaton. 1985. Soil fertility and fertilizers. $4^{\text {th }}$ Edition, Macmillan Publication Co., New York, USA. p. 754.

Uhm, K B, J S Hyun and K M Choi. 1985. Effects of the different levels of nitrogen fertilizer and planting space on the population growth of the brown planthopper. Res. Report RDA: P. M. \& U., 27: 79-85.

Urabe, J and R W Sterner. 2001. Contrasting effects of different types of resource depletion on life-history traits in Daphnia. Funct. Ecol., 15: 165-174.

Wyn Jones, R J. 1999. Cytoplasmic potassium homeostasis: Review of the evidence and its implication. In: DM Oosterhuis and GA Berkowitz (eds.) Frontiers in Potassium Nutrition: New Perspectives on the Effects on Potassium on Physiology of Plants. Crop Sci. Soc. Am., Special Publication, Potash and Phosphate Institute, Atlanta, Georgia, USA. pp. 13-22.

Zeigler, R S and A Barclay. 2008. The relevance of rice. Rice, 1: 3-10. 